\title{
Surgical treatment of metastatic diseases to the lung
}

\author{
Jarosław Religioni, Tadeusz Orłowski \\ Department of Surgery, Institute of Tuberculosis and Lung Diseases, Warsaw, Poland
}

Kardiochir Torakochir Pol 2020; 17 (2): 52-60

\begin{abstract}
Introduction: The problem of treating secondary cancer is very controversial. Huge progress in its treatment began in the 1970s with the introduction of chemotherapy. In the surgical aspect Pastorino's work published in 1997 was a milestone. To this day, most authors cite its research results.

Aim: The task is to answer the question what tactics to follow in the surgical treatment of patients with secondary cancer affecting the respiratory system.

Material and methods: Retrospective studies were conducted on a group of 577 patients. Men prevailed slightly. The average age was 56 years. Surgical access used in the vast majority of cases was anterolateral thoracotomy. Wedge resection was the most common scope of surgery. Lymph nodes were not removed as standard. Single and multifactorial statistical surveys were conducted (Kaplan-Meier estimator and multifactorial Cox regression analysis).

Results: A total of 1,058 operations were performed during which 1889 metastases were removed. Negative tissue margins were obtained in $90.4 \%$. The median survival was 47 months. Complications occurred in 76 patients, which constituted $7.1 \%$ of performed procedures. There were 3 perioperative deaths.

Conclusions: It was found that the factors negatively affecting survival were lack of radicalism, size of the metastasis $>3 \mathrm{~cm}$, and number of metastases $>1$. The factors positively influencing survival were a longer time than primary surgery and a greater number of operations. Histological diagnosis differentiated patient survival.
\end{abstract}

Key words: pulmonary metastases, surgical treatment, prognostic factors, long-term results.

\section{Introduction}

The main problem at the stage of generalization of the cancer process is striving to extend the survival time with symptomatic palliative treatment and optimize the time for surgical treatment. Since the first publication that appeared in the second half of the nineteenth century, there have been thousands of treatises dealing with this issue.

\section{Streszczenie}

Wprowadzenie: Problem leczenia wtórnej choroby nowotworowej budzi wiele kontrowersji. Przełomem było wprowadzenie chemioterapii w latach 70. XX wieku. W aspekcie chirurgicznym kamieniem milowym była praca Pastorino opublikowana w 1997 roku. Do dzisiaj większość autorów powołuje się na wyniki jego badań.

Cel pracy: Praca ma odpowiedzieć na pytanie, jaką taktykę postępowania należy przyjąć w leczeniu chirurgicznym cierpiących na wtórną chorobę nowotworową zajmującą układ oddechowy. Materiał i metody: Badania retrospektywne przeprowadzono w grupie 577 chorych. Nieznacznie przeważali mężczyźni. Średni wiek to 56 lat. Dostępem operacyjnym stosowanym w większości przypadków była torakotomia przednio-boczna. Najczęstszym zakresem zabiegu była resekcja klinowa. Nie usuwano standardowo węzłów chłonnych. Prowadzono badania statystyczne jedno- i wieloczynnikowe (estymator KaplanaMeyera i wieloczynnikowa analiza regresji Coksa).

Wyniki: Przeprowadzono łącznie 1058 operacji, podczas których usunięto 1889 przerzutów. Ujemne marginesy tkankowe uzyskano w 90,4\%. Mediana przeżycia wyniosła 47 miesięcy. Powikłania wystąpiły u 76 pacjentów, co stanowiło 7,1\% przeprowadzonych operacji. Stwierdzono 3 zgony okołooperacyjne.

Wnioski: Czynnikami negatywnie wpływającymi na przeżycie były brak radykalizmu, wielkość przerzutu $>3 \mathrm{~cm}$, liczba przerzutów >1, natomiast czynnikami pozytywnie wpływającymi na przeżycie - dłuższy czas od operacji pierwotnej i większa liczba operacji. Rozpoznanie histologiczne różnicował czas przeżycia pacjentów.

Słowa kluczowe: przerzuty do płuc, leczenie chirurgiczne, czynniki rokownicze, wyniki odległe.

The problem that prevented the objectification of the obtained results was the fact that they were always based on retrospective studies. Attempts were made to compare groups of patients undergoing surgical treatment with patients who could not be offered such a procedure. However, this methodology was incorrect due to the different stages of the disease in both groups. However, in the case of pa-

Address for correspondence: Jarosław Religioni, Department of Surgery, Institute of Tuberculosis and Lung Diseases, 26 Płocka St, 01-129 Warsaw, Poland, phone: +48 6023346 72, e-mail: j.religioni@igichp.edu.pl

Received: 19.03.2020, accepted: 15.04.2020. 
tients who have already been qualified for surgery, they still cannot be defined as a homogeneous group. They differ in demographic data, histological type, primary tumor starting point, and finally the criteria used for surgery and surgical techniques. In order to systematize the treatment of metastatic changes in the lungs, numerous associations and registers of patients with such a diagnosis were established. One of them is the International Registry of Lung Metastases (IRLM). In 1997, based on these data, Pastorino published a paper based on an analysis of 5206 cases. This allowed him to make recommendations regarding the qualification of patients with metastatic disease for surgical treatment [1]. The disadvantage of this research program was that data about the patients treated came from many medical centers. Therefore, it should be assumed that this was not a homogeneous group of patients. In the available literature, there are few papers based on large groups of patients treated in only one center [2].

\section{Aim}

The aim of the study is to assess the long-term results of surgical treatment of lung metastases. This applies to the qualification phase of the surgery, the surgical tactics and the long-term strategy of treating chronic, generalized cancer.

\section{Material and methods}

A group of 577 patients treated at the Institute of Tuberculosis and Lung Diseases in Warsaw for 15 years was examined. Patients qualified for treatment were not selected in any way. The generally accepted criteria for surgical treatment of lung metastases were followed. All patients underwent computed tomography of the chest organs before surgery and in case of justified suspicion of the extent of the abdominal growth process. In doubtful cases, positron emission tomography-computed tomography (PET-CT) examination was also performed. Depending on the location of the primary outbreak as well as the location of secondary outbreaks in the parenchyma endoscopic examination in the gastrointestinal tract and respiratory system was performed. In total, 1058 operations were performed. Metastasectomy was performed once in $51.1 \%$ of cases. Other patients were operated on several times. Surgical access was in most cases anterolateral thoracotomy. Most often the scope of the procedure was wedge resection, followed by lobectomy, segmentectomy and most rarely pneumonectomy. Lymph nodes were not removed as standard. Lymphadenectomy was performed in 332 patients. The average time from resection of the primary tumor to surgery to remove metastases from the lungs was 42.5 months. The most common tumor starting point was the large intestine, then the kidney followed by the osteoarticular system and soft tissues. Adenocarcinoma, clear cell carcinoma and sarcoma were most commonly diagnosed. In order to assess the long-term results of treatment, the division proposed by the International Registry of Lung Metastases was also taken into account, in which
4 groups with different disease stages are distinguished, in which the prognosis is significantly different. It is based on disease-free interval (DFI), the number of metastases in the pulmonary parenchyma and the possibility of radical resection of the metastases. Group 1 - no risk factors - DFI over 36 months, single metastasis, possibility of complete resection. Group 2 - one risk factor - DFI under 36 months or multiple metastases, the possibility of complete resection. Group 3 - two risk factors - DFI less than 36 months and numerous metastases with the possibility of complete resection. Group 4 - no resection possible. Group 4 was not assessed in the analyzed material. It was established that the patients we operated on in $78.6 \%$ of cases were in the second and third risk groups. Some analyses were performed on the entire data set by analyzing overall survival, surgery radicality and the presence of lymph node metastases. The remaining studies were conducted on a set of data on radically operated patients, without lymph node metastases and those without lymph nodes. Information on the possible date of death was obtained from the Ministry of Digitization.

\section{Statistical analysis}

In statistical surveys, the study group was divided into two parts. The first comprised all patients who underwent surgery. In the second there were patients operated on radically, without lymph node metastases, and those who had not had them removed and thus examined histologically. One-way dependencies were analyzed using Kaplan-Meier estimators and the log-rank test. The results are presented graphically in the form of survival curves and tabularly giving the median survival as well as 3- and 5-year survival estimators with appropriate $95 \%$ confidence intervals. Onefactor analyses were supplemented with the multifactorial Cox model. The variables were selected using the backward method. The calculations were carried out using the R 3.6.1 program (R Core Team (2019). R: A language and environment for statistical computing. R Foundation for Statistical Computing, Vienna, Austria. URL https://www.R-project.org/).

\section{Results}

Men slightly dominated in the analyzed group. The age ranged from 18 to 85 years (Table I).

In total, 1058 operations were performed. One procedure was performed in 295 patients, and in other cases the operations were repeated. A maximum of 9 operations were performed. Unilateral operations were performed in $61.6 \%$ of cases. Disease-free time was taken from the primary focus resection to the first resection of the secondary focus from the lungs. It was 42.5 months on average in the study group and ranged from 1 to 280 months. The most common primary focus was the large intestine. The next organ was the kidney, osteoarticular system/soft tissues, breasts, reproductive organ, testis, and liver. A separate group consisted of patients with other primary locations of proliferative disease. They were found in 65 patients. Among them, the most common were cancers of the pancreas, larynx, body 
Table I. Demographic data

\begin{tabular}{lcc} 
Parameter & & Results \\
\cline { 2 - 3 } Sex & Female & $255(44.2 \%)$ \\
\hline \multirow{2}{*}{ Age } & Male & $322(55.8 \%)$ \\
& Mean \pm SD & $56.7 \pm 14.9$ \\
& Min.-max. & $18-85$ \\
\hline
\end{tabular}

Table II. Treatment data including histology

\begin{tabular}{|c|c|c|c|}
\hline Parameter & & & Results \\
\hline $\begin{array}{l}\text { General number } \\
\text { of operation }\end{array}$ & & $n$ & 1058 \\
\hline \multirow{4}{*}{$\begin{array}{l}\text { Number of } \\
\text { operations } \\
\text { in the patient }\end{array}$} & 1 & $n(\%)$ & $295(51.1)$ \\
\hline & 2 & $n(\%)$ & $181(31.4)$ \\
\hline & 3 & $n(\%)$ & $50(8.7)$ \\
\hline & $4+$ & $n(\%)$ & $51(8.8)$ \\
\hline \multirow[t]{2}{*}{ Operation } & Unilateral & $n(\%)$ & $354(61.6)$ \\
\hline & Bilateral & $n(\%)$ & $221(38.4)$ \\
\hline $\begin{array}{l}\text { Disease-free } \\
\text { interval (DFI) }\end{array}$ & $\begin{array}{l}\text { Number } \\
\text { of months }\end{array}$ & Mean \pm SD & $42.5 \pm 47.9$ \\
\hline \multirow[t]{8}{*}{ Primary tumor site } & Colon & $n(\%)$ & $167(28.9)$ \\
\hline & Kidney & $n(\%)$ & 159 (27.6) \\
\hline & Bones/soft tissue & $n(\%)$ & 89 (15.4) \\
\hline & Gynecologic & $n(\%)$ & $31(5.4)$ \\
\hline & Breast & $n(\%)$ & $35(6.1)$ \\
\hline & Germ cell & n (\%) & $23(4)$ \\
\hline & Liver & $\mathrm{n}(\%)$ & $8(1.4)$ \\
\hline & Others & n (\%) & 65 (11.3) \\
\hline \multirow[t]{8}{*}{ Histological type } & Adenocarcinoma & $n(\%)$ & 191(33.2) \\
\hline & $\begin{array}{l}\text { Renal cell } \\
\text { carcinoma }\end{array}$ & $n(\%)$ & $153(26.6)$ \\
\hline & Sarcoma & $n(\%)$ & $100(17.4)$ \\
\hline & $\begin{array}{l}\text { Other epithelial } \\
\text { cancers }\end{array}$ & $n(\%)$ & 66(11.5) \\
\hline & Germ cell & $n(\%)$ & $22(3.8)$ \\
\hline & Melanoma & $n(\%)$ & $19(3.3)$ \\
\hline & $\begin{array}{c}\text { Squamous } \\
\text { cell carcinoma }\end{array}$ & $n(\%)$ & $18(3.1)$ \\
\hline & $\begin{array}{c}\text { Other } \\
\text { non-epithelial }\end{array}$ & $n(\%)$ & $4(0.7)$ \\
\hline
\end{tabular}

shells, and thyroid. Other locations were less common and concerned salivary glands, facial skeleton, prostate gland, and bladder. The dominant histological type was adenocarcinoma, followed by clear cell carcinoma and sarcoma. In cases of uncertain histological data, a group of other cancers was identified. There were 66 cases of malignant tumors of epithelial and 4 non-epithelial origin. Altogether, epithelial malignancies were found in 428 cases. In addition, 279 benign, most often inflammatory nodules were removed in 99 patients. No correlation was found between the type of metastases removed and the incidence of noncancerous nodules (Table II).

In the study group, 391 patients had additional treatment before or more often after primary tumor removal. Of these patients, chemotherapy was used in 289 patients, and radiation in 116 patients. Some patients had both treatment methods. In 137 patients another operation was performed between primary focus removal and metastasectomy. Most frequently, metastatic lesions from other organs were resected or reoperated due to recurrence of the primary focus. In total, 391 patients received other treatments between the removal of the primary tumor and metastasectomy 542 times. In the case of metastasectomy, the most common resection was wedge lung resection, which was performed in 441 patients. The number of procedures in this type of resection ranged from 1 to 8 , with one-time surgery being the most common. Segmentectomy was performed in 47 patients. Lobectomy was performed in 142 patients. The entire lung was removed in 12 patients. In eight cases it was a complementary pneumonectomy, and in four cases it was a one-off operation in this range due to the large tumor size or central lesion location. In total, 943 pulmonary resections were performed. The remaining 41 procedures were performed due to chest wall or mediastinal metastatic tumors. In addition, 71 resections were performed in 46 patients before admission to our hospital. Surgery was continued at our center due to recurrence of the disease. Altogether 1058 treatments were performed in the study group. In the vast majority of cases, the preferred operative access was anterolateral thoracotomy. Different openings of the chest were also used for multiple operations on the same patient. If in the first stage videothoracoscopy was performed (with single sub-pleural metastases), then in the case of the next surgery on the same side, thoracotomy was performed. This situation occurred in 11 cases (out of 58 videothoracoscopies). The possibility of adhesions after the first surgery was taken into account, but above all the better possibilities of assessing palpatory pulmonary parenchyma after surgery had been guided. In one case, following a wedge resection performed via thoracotomy, a videothoracoscopic lower lobectomy was performed due to relapse. When qualifying for surgery and the planned method of opening the chest, the number of lesions to be resected, their size and location in the pulmonary parenchyma were taken into account. Surgical access in 520 patients was anterolateral thoracotomy (in 16 cases bilateral thoracotomy at the same time), 52 patients underwent videothoracoscopy, and longitudinal sternotomy was used in 7 cases. Another access with or without the pleural cavity was used in 34 patients. In four cases, exploratory thoracotomy was performed (Table III).

Complications were found in 76 patients, which constituted $13.1 \%$ of the study group. However, taking into account the total number of operations (1058) they accounted for only $7.1 \%$. There were 3 deaths, twice on the seventh day, once 2 months after the operation. In the analyzed group complications unrelated to the technical con- 
Table III. Previous treatment, operation scope, operational access

\begin{tabular}{|c|c|c|}
\hline Variable & & Results \\
\hline $\begin{array}{l}\text { Previous treatment before metastasectomy } \\
\text { combined: }\end{array}$ & & $391(67.8 \%)$ \\
\hline Radiotherapy & & $116(29.7 \%)$ \\
\hline Chemotherapy & & $289(73.9 \%)$ \\
\hline Other operations & & $137(35 \%)$ \\
\hline \multicolumn{3}{|l|}{ Operation scope: } \\
\hline Patients undergoing wedge resection & & $441(76.4 \%)$ \\
\hline \multirow[t]{8}{*}{ Number of wedge resections in the patient } & 1 & $263(59.6 \%)$ \\
\hline & 2 & $119(27 \%)$ \\
\hline & 3 & $33(7.5 \%)$ \\
\hline & 4 & $13(2.9 \%)$ \\
\hline & 5 & $5(1.1 \%)$ \\
\hline & 6 & $6(1.4 \%)$ \\
\hline & 7 & $1(0.2 \%)$ \\
\hline & 8 & $1(0.2 \%)$ \\
\hline Number of performed wedge resections & & 728 \\
\hline Patients undergoing segmentectomy & & $47(8.1 \%)$ \\
\hline \multirow[t]{3}{*}{ Number of segmentectomies in the patient } & 1 & $44(93.6 \%)$ \\
\hline & 2 & $2(4.3 \%)$ \\
\hline & 3 & $1(2.1 \%)$ \\
\hline Number of performed segmentectomies & & 51 \\
\hline Patients undergoing lobectomy & & $142(24.6 \%)$ \\
\hline \multirow[t]{2}{*}{ Number of lobectomies in the patient } & 1 & $132(93.0 \%)$ \\
\hline & 2 & $10(7.0 \%)$ \\
\hline Number of performed lobectomies & & 152 \\
\hline Patient undergoing pneumonectomy & & $12(2.1 \%)$ \\
\hline Number of pneumonectomies in the patient & 1 & $12(100 \%)$ \\
\hline Number of performed pneumonectomies & & 12 \\
\hline \multicolumn{3}{|l|}{ Operational access: } \\
\hline Patients who have had videothoracoscopy & & $52(9.0 \%)$ \\
\hline \multirow{2}{*}{$\begin{array}{l}\text { Number of videothoracoscopies in the } \\
\text { patient }\end{array}$} & 1 & $46(88.5 \%)$ \\
\hline & 2 & $6(11.5 \%)$ \\
\hline $\begin{array}{l}\text { Total number of videothoracoscopies } \\
\text { performed }\end{array}$ & & 58 \\
\hline $\begin{array}{l}\text { Patient who have had anterolateral } \\
\text { thoracotomy }\end{array}$ & & $520(90.1 \%)$ \\
\hline \multirow[t]{8}{*}{ Number of thoracotomies in the patient } & 1 & $283(54.4 \%)$ \\
\hline & 2 & $155(29.8 \%)$ \\
\hline & 3 & $47(9 \%)$ \\
\hline & 4 & $21(4 \%)$ \\
\hline & 5 & $5(1 \%)$ \\
\hline & 6 & $3(0.6 \%)$ \\
\hline & 7 & $4(0.8 \%)$ \\
\hline & 8 & $2(0.4 \%)$ \\
\hline Total number of thoracotomies performed & & 905 \\
\hline Sternotomy & 1 & $7(100 \%)$ \\
\hline Patients with other access - chest wall tumor & & $30(5.2 \%)$ \\
\hline \multirow{2}{*}{$\begin{array}{l}\text { Number of operations on the patient using } \\
\text { other access }\end{array}$} & 1 & $26(86.7 \%)$ \\
\hline & 2 & $4(13.3 \%)$ \\
\hline Total number of operations using other access & & 34 \\
\hline
\end{tabular}

Table IV. Complications $(N=76)$ - number and detailed description

\begin{tabular}{lc} 
Complication & Results \\
\hline Rethoracotomy: & 18 \\
\hline Bleeding & 14 \\
\hline Air leak & 2 \\
\hline Esophageal damage & 1 \\
\hline Stomach damage & 1 \\
\hline Prolonged drainage - air leak, air space, hematoma & 16 \\
\hline Respiratory failure requiring controlled breathing/ & 12 \\
\hline bronchoscopy & \\
\hline Postoperative kidney failure & 7 \\
\hline Dehiscence of the postoperative wound & 6 \\
\hline Postoperative pleural empyema & 5 \\
\hline Death: & 3 \\
\hline ARDS - seventh day after surgery & 1 \\
\hline Respiratory failure - seventh day after surgery & 1 \\
\hline $\begin{array}{l}\text { Hemorrhage - reoperation - circulatory failure sixtieth } \\
\text { day after surgery }\end{array}$ & 1 \\
\hline Pulmonary embolism & 3 \\
\hline Circulatory failure & 2 \\
\hline Ischemic stroke & 1 \\
\hline Laryngeal nerve palsy & 1 \\
\hline Horner syndrome & 1 \\
\hline Lymphorrhea & 1 \\
\hline
\end{tabular}

sequences of the surgery occurred in 27 patients. Detailed information is presented in the next table (Table IV).

1889 metastases were removed during all the procedures. One change was removed in 285 (51.5\%) patients, 4 and more in 129 (23.1\%) patients. In addition, 279 benign, most often inflammatory nodules were removed in 99 patients. There is no correlation between the type of metastases removed and the incidence of non-cancerous nodules. The size of the removed metastatic tumors was initially divided into four groups: in the range $<1 \mathrm{~cm}, 1-2 \mathrm{~cm}$, $2-3 \mathrm{~cm}$ and $3 \mathrm{~cm}$ and more. Because patients with more than one metastasis often had lesions of varying sizes, they were a heterogeneous group. Therefore, their size was grouped in three ranges, namely $<2 \mathrm{~cm}, 2-3 \mathrm{~cm}$ and $3 \mathrm{~cm}$ and more (Table V). Lymph nodes were not removed as standard. In cases where significant imaging was found in imaging or intraoperative examinations, lymphadenectomy was performed. The radicality of the surgery was also examined. Negative tumor margins were achieved in 508 patients, which constituted $90.4 \%$ of the study group. In the remaining 54 (9.6\%) patients, the R1 status was found in the pathomorphological examination. Cases of recurrence of the disease after resection of lung metastases were also analyzed. This group includes patients who have new lesions in the already operated or opposite lung after the first metastasectomy. Finally, in the whole study group, recurrence after resection was found in 163 (28.6\%) patients (Table VI). For statistical purposes, patients with the R1 status in the tissue margin were excluded from the study. 
Table V. Metastases

\begin{tabular}{|c|c|c|}
\hline Variable & & Results \\
\hline $\begin{array}{l}\text { Total number of metastases } \\
\text { resected }\end{array}$ & & 1889 \\
\hline \multirow[t]{4}{*}{ Number of metastases in 1 patient } & 1 & 285 (51.1\%) \\
\hline & 2 & $94(16.8 \%)$ \\
\hline & 3 & $50(9 \%)$ \\
\hline & 4 and more & $129(23.1 \%)$ \\
\hline \multirow[t]{4}{*}{ Range of tumor size } & $<1 \mathrm{~cm}$ & $103(18.7 \%)$ \\
\hline & $1-2 \mathrm{~cm}$ & $201(36.4 \%)$ \\
\hline & $2-3 \mathrm{~cm}$ & $104(18.8 \%)$ \\
\hline & $3 \mathrm{~cm}$ and more & $144(26.1 \%)$ \\
\hline \multirow[t]{3}{*}{ Range of tumor size } & $<2 \mathrm{~cm}$ & $304(55.1 \%)$ \\
\hline & $2-3 \mathrm{~cm}$ & $104(18.8 \%)$ \\
\hline & $3 \mathrm{~cm}$ and more & $144(26.1 \%)$ \\
\hline Benign nodules & & 279 \\
\hline
\end{tabular}

Table VI. Radicalism, recurrence rate

\begin{tabular}{lll}
\hline Radicalism $\left(N^{*}=562\right)$ & No & $54(9.6 \%)$ \\
\cline { 2 - 3 } & Yes & $508(90.4 \%)$ \\
\hline Recurrence after resection $\left(N^{*}=570\right)$ & No & $407(71.4 \%)$ \\
\cline { 2 - 3 } & Yes & $163(28.6 \%)$ \\
\hline
\end{tabular}

*Number of patients with available data.

In the examined group of patients, the average survival without taking into account any additional factors was 47 months, $58 \%$ survived for 3 years, and $41 \%$ for 5 years.

\section{Discussion and conclusions}

The lungs are the second most common metastatic site after the liver, which accounts for $30 \%$ of secondary malignancies. In autopsy studies of patients who died from primary extrapulmonary cancer, $20 \%$ to $50 \%$ have pulmonary metastases at the time of death. Of this group, approximately $10-15 \%$ of patients have metastases limited only to the lungs. Only about $2 \%$ of all patients with such a diagnosis can be subjected to surgical treatment [3]. Usually, the disease is asymptomatic and is detected accidentally during examinations determining the stage of primary cancer or during postoperative follow-up. In the case of the habitual location of the lesion, there are symptoms typical of a lung tumor. Rarely, peripheral localization has pneumothorax as a consequence of pulmonary pleural damage or pain resulting from chest wall infiltration [4]. Alternative methods of local treatment in patients who cannot undergo surgery are stereotactic radiotherapy, laser ablation, cryoablation or thermoablation. There are also actions involving the isolated administration of the drug to the tumor (gemcitabine, deoxycytidine, melphalan). The goal of treatment is to strive to prolong survival or symptomatic palliative treatment [5]. Before the procedure, computed tomography of the chest and possibly the abdominal cavity is necessary. In the analyzed material, all patients under- going treatment had such tests not earlier than a month before the surgery. PET-CT examination is also applicable, but its sensitivity is limited and according to various researchers is around $65 \%$. In colorectal cancer it is $68 \%$, in kidney cancer $71 \%$, in sarcomas $44 \%$. Before metastasectomy, all extrapulmonary malignancies should be localized and cured. Irrespective of the assessment of the stage of proliferative disease, it is also obligatory to perform a panel of tests as for lung cancer surgery. These are mainly functional tests of the respiratory system and the circulatory system. This is especially important at subsequent metastasectomies when the assessment of predictable functional parameters of the respiratory system is significantly impeded. Therefore, it is recommended to perform breathing mechanics and exercise tests in such cases. When analyzing cardiovascular fitness, cardiac ultrasound should be considered in selected cases (cardiac history, subsequent metastasectomies) mainly in terms of assessing the risks associated with the formation of pulmonary hypertension after pulmonary resection. Thorough preoperative evaluation in both oncological and systemic terms is the key to achieving satisfactory results in the surgical treatment of lung metastases. Differential diagnosis should also consider the presence of primary lung cancer as well as benign lesions. Therefore, for individual tumors, intraoperative examination was performed as standard to determine the extent of pulmonary resection. This rule is not obligatory only in the case of previously established reliable histological diagnosis. However, it should be remembered to perform lymphadenectomy as in primary lung cancer with anatomical resection and uncertain histological diagnosis prior to or intraoperatively performed. With the planned scope of the procedure, one should take into account that the preoperative radiological assessment and intraoperative macroscopic examination are not entirely clear cut. It should also be taken into account that lung lesions may not have a cancer etiology. Metastatic lesions are typically well demarcated. Usually they are sub-pleural or localized in the external pulmonary fields. Primary cancers are usually single, have irregular outlines and are more often centrally located. Thus, with multifocal disease, the likelihood of metastasis is greater except for wallpapers adenocarcinoma, which can also occur in multifocal form. A new focus in pulmonary parenchyma in a patient with a history of cancer turns out to be cancer in $80 \%$ of cases compared to $63 \%$ in patients without a history of cancer. With a lesion size $<1 \mathrm{~cm}$, it is $67 \%$ malignant, with a size $>3 \mathrm{~cm}$, malignancy is found in $91 \%$. For size changes up to $3 \mathrm{~cm}$, the probability of metastasis or primary cancer is similar. With lesions above $3 \mathrm{~cm}$, primary lung cancer is more often diagnosed [6]. The criteria conditioning the use of surgical treatment of lung metastases are:

1) The occurrence of lung lesions known as metastases with the possibility of their radical resection.

2) No contraindications from other organs.

3) The primary focus is oncologically controlled.

4) No other extrapulmonary metastatic foci. 
Table VII. Survival in all data sections - in general and depending on the radicalism of the operation

\begin{tabular}{|c|c|c|c|c|c|c|c|}
\hline Variable & Level & Observations & Events & $\begin{array}{l}\text { Median survival time } \\
\qquad(95 \% \mathrm{CI})\end{array}$ & $\begin{array}{l}\text { 3-year survival } \\
(95 \% \mathrm{CI})\end{array}$ & $\begin{array}{l}\text { 5-year survival } \\
(95 \% \mathrm{Cl})\end{array}$ & $P$-value \\
\hline Overall & Overall & 575 & 349 & $47.0(43.0-53.0)$ & 58.01 (53.99-62.34) & $41.34(37.14-46.00)$ & \\
\hline \multirow[t]{2}{*}{ Radicalism } & No & 64 & 47 & $28.0(21.0-51.0)$ & $44.02(33.22-58.34)$ & $25.91(16.46-40.80)$ & 0.003 \\
\hline & Yes & 503 & 297 & $47.0(43.0-60.0)$ & 59.59 (55.31-64.20) & 43.35 (38.84-48.38) & \\
\hline
\end{tabular}

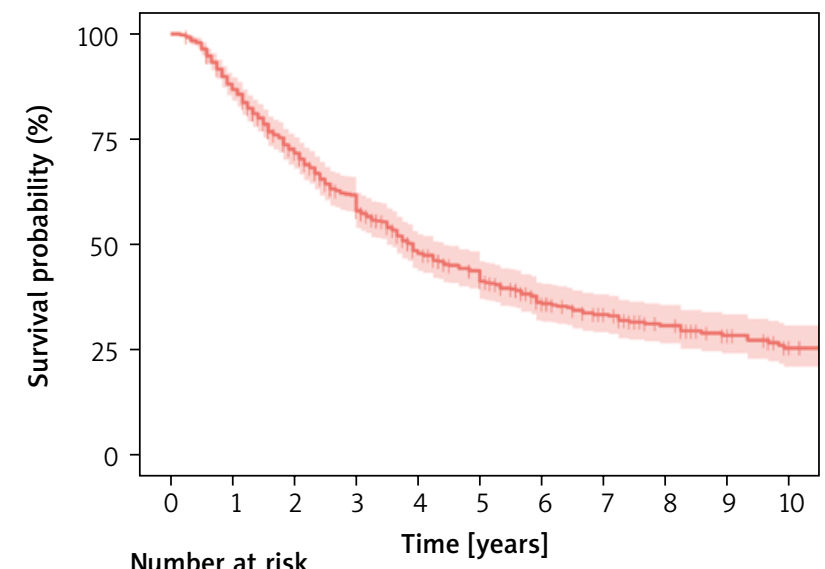

\begin{tabular}{|c|c|c|c|c|c|c|c|c|c|c|}
\hline 575 & 503 & 388 & 308 & 208 & 175 & 121 & 98 & 73 & 52 & 40 \\
\hline 0 & 1 & 2 & 3 & 4 & 5 & 6 & 7 & 8 & 9 & 10 \\
\hline
\end{tabular}

Figure 1. Overall survival, all patients

There are also indications for metastasectomy in some patients who do not meet the above criteria, for example:

1) The situation when we cannot rule out a new primary outbreak of lung cancer.

2) There are clinical symptoms resulting from metastases and they require surgical intervention (e.g. hemoptysis, emphysema, atelectasis).

3) We have no established histological diagnosis despite the minimally invasive procedures used previously and pathologically changed tissue should be obtained to determine the treatment strategy [7].

The main factor influencing the prognosis is the radical removal of the changes. According to the literature, complete resection of metastatic changes in relation to unfortunate surgery enables 35-month survival compared to 15 -month survival. Survival after radical metastasectomy is 5 years in 36\%, 10 years in 26\%, 15 years in $22 \%$ of cases. After non-radical metastasectomy, survival is 5 years in $13 \%, 10$ years in $7 \%$ of cases $[1,8]$. In our study, radicalism in the unchanged surgical margin was achieved in 508 patients, which constituted $90.4 \%$. In the remaining 54 patients constituting $9.6 \%$ the R1 status was found in pathomorphological examination. The average survival time was 47 months compared to 28 months in the absence of radicality. With complete surgery, 3- and 5-year survival was $60 \%$ and $43 \%$, respectively, compared to $44 \%$ and $26 \%$ in the absence of radicality. These results are statistically significant (Table VII, Figures 1, 2). Cases with a short time of appearance of lung lesions since the primary focus resec-

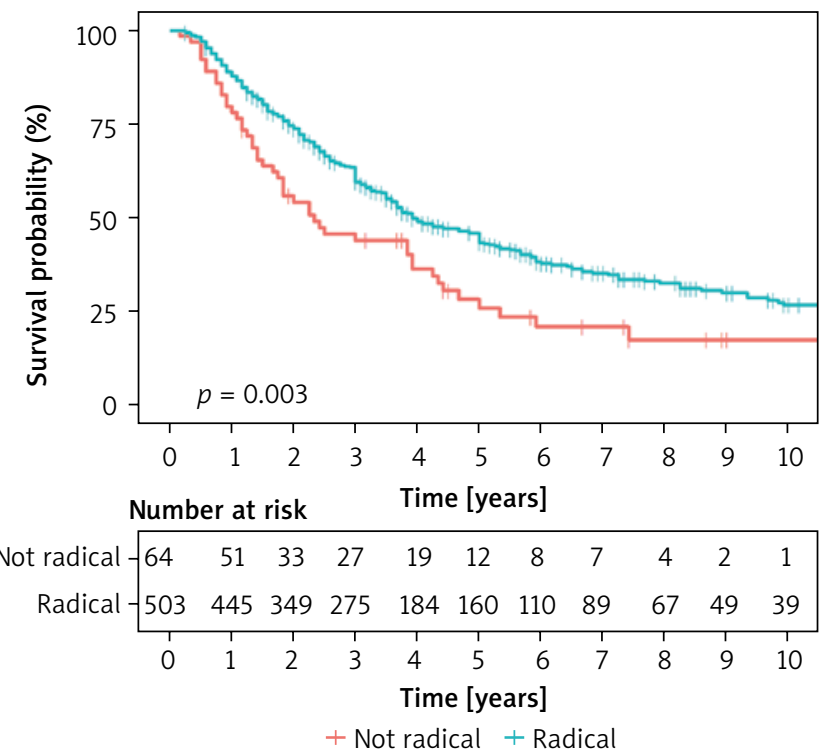

Figure 2. Radicalism of operations

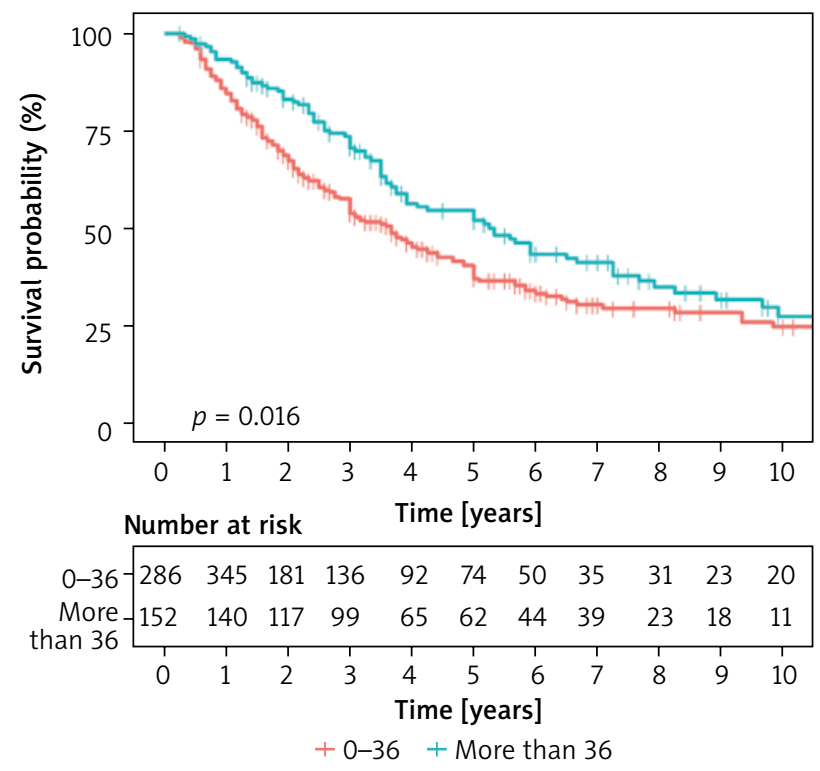

Figure 3. Disease-free interval

tion have a negative prognosis. The limit value confirmed by numerous authors is the period of 36 months from the date of resection of the primary focus until the confirmation of secondary changes. Our studies confirm this period and are statistically significant (Figure 3). Based on the stage of the disease according to IRLM, it was established that the patients operated on by us in $78.5 \%$ of cases were in the second and third risk groups. Despite this, better survival results were obtained compared to most data published. 


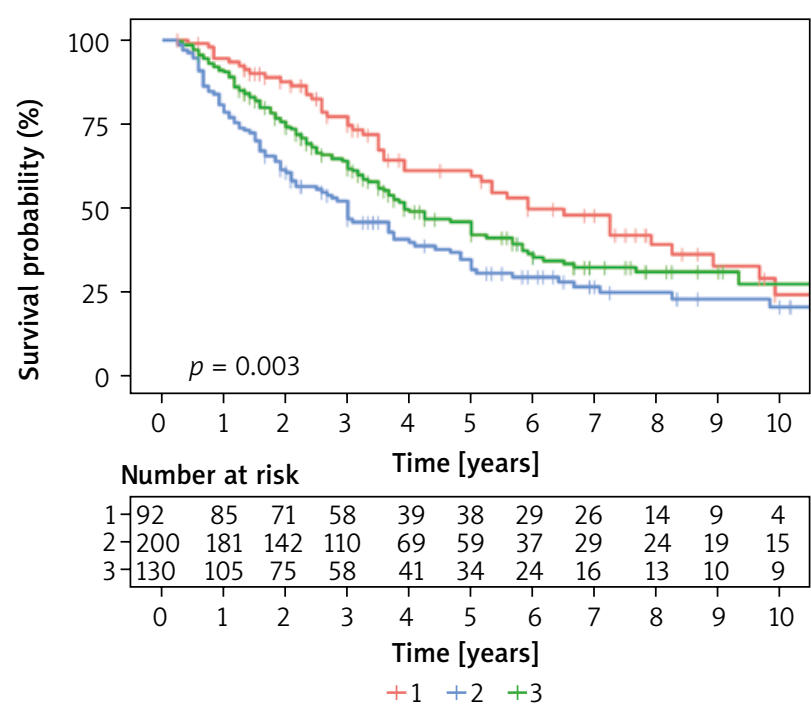

Figure 4. Risk groups

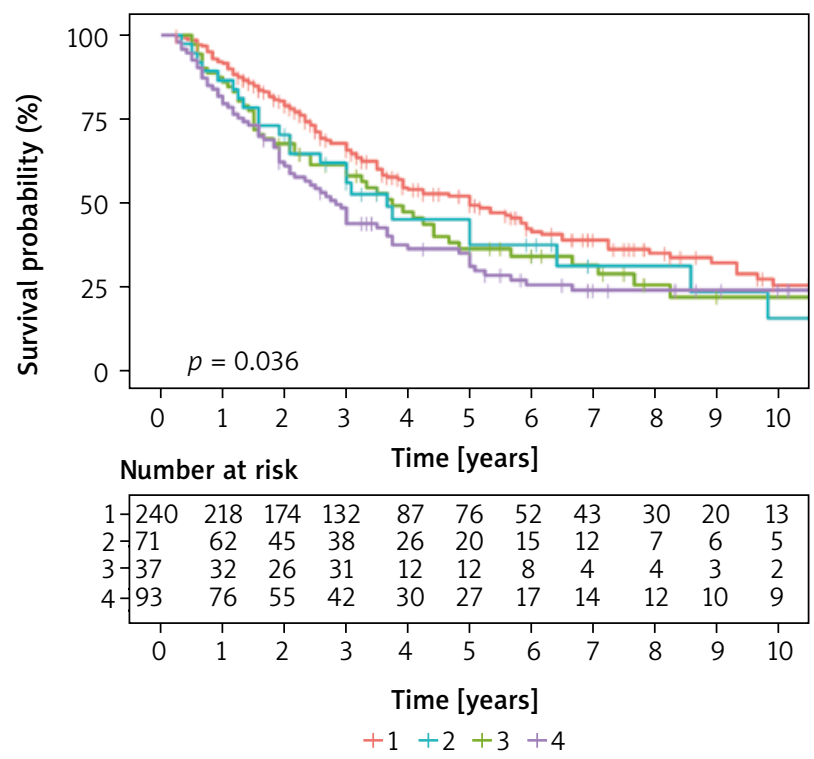

Figure 5. Number of metastases

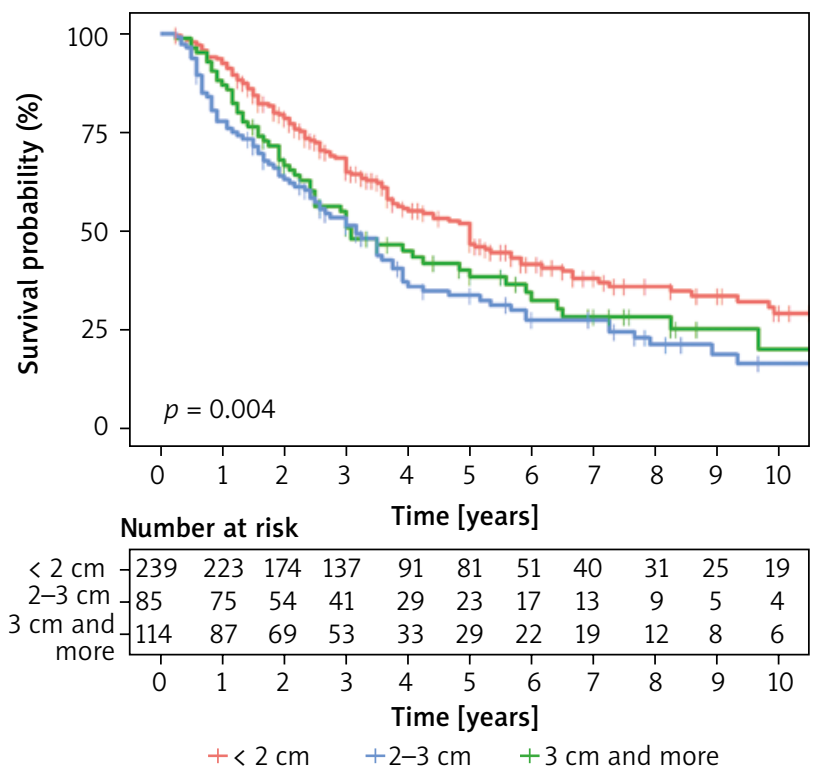

Figure 6. Range of tumor size
Statistical analysis confirmed that risk factors affect survival (Figure 4). A large number of metastatic lesions indicates a more advanced stage of secondary proliferative disease. According to IRLM, 43\% survive 5 years with 1 metastatic lesion, 34\% survive 5 years with 2-3 metastases and $27 \%$ survive 5 years with 4 or more lesions. According to other researchers, $71 \%$ survive 2 years and $45 \% 5$ years with one metastasis. Correspondingly, $66 \%$ survive 2 years and $44 \%$ 5 years with 4 or more lesions (2). According to our findings, the median survival at 1 metastasis was 60 months. $49 \%$ survived 5 years with 1 metastasis, 36\% survived 5 years with 2 metastases, 37\% with 3 lesions, and at 4 or more 5 years $31 \%$ survived. Statistical analysis of one factor and multifactorial analysis showed that the prognostic factor for successful survival was the presence one tumor in the pulmonary parenchyma (Figure 5). Shorter survival time in patients with multiple metastases is undoubtedly associated with a higher stage of secondary hyperplastic disease and less radical surgery despite the macroscopic features of completeness. An additional factor hindering the maintenance of a negative tissue margin are subsequent operations performed on the same side in the event of a relapse. Postoperative changes hamper proper intraoperative assessment. Based on the available literature, it can be assumed that in cases of up to three metastases, radical metastasectomy is performed in $80 \%$ of cases, and when the number of changes in preoperative CT was more than 6 the chance for radical resection is in the range of $20 \%$ [6].

The size of the changes removed was also assessed. A single and multifactorial statistical analysis showed that the prognostic factor that affected the survival time was tumor size above $3 \mathrm{~cm}$ (Figure 6). Some centers recommend lymph node removal only in patients with suspected involvement in imaging tests. Other doctors perform lymphadenectomy on all patients. However, most researchers do not recommend routine lymphadenectomy for lung metastases unless they are significantly enlarged. Lymph nodes were not removed as standard in the study group. Generally, in cases where imaging examinations were found to have significant enlargement, pre-operative mediastinoscopy, bronchofiberosonography or PET-CT examination was performed. Then the patient was qualified or not for resection of lung lesions. In cases where intra-operative node enlargement was found, which was not determined during the qualification phase, lymphadenectomy or sampling was performed. In 332 patients lymph nodes were taken for examination or removed according to the procedure used for lung cancer resection. In 234 cases, lymph nodes were not collected. Metastases were found in 49 cases, which constituted $8.65 \%$ of the entire study group and $15 \%$ of the group in which lymph nodes were collected. In statistical studies of the entire data set, no statistically significant differences were found in survival for patients with or without lymph nodes (Table VIII). It should be assumed that lymph node involvement is a negative prognostic factor. Sarcomas are metastatic to the lungs via the bloodstream and are mainly located in the pulmonary parenchyma. Kidney, colorectal and melanoma cancers metastasize by the lymphatic tract, 
Table VIII. Survival in all data sections depending on the presence of lymph node metastasis

\begin{tabular}{|c|c|c|c|c|c|c|c|}
\hline Variable & Level & Observations & Events & $\begin{array}{l}\text { Median survival time } \\
\qquad(95 \% \mathrm{CI})\end{array}$ & $\begin{array}{l}\text { 3-year survival } \\
(95 \% \mathrm{Cl})\end{array}$ & $\begin{array}{l}\text { 5-year survival } \\
(95 \% \mathrm{CI})\end{array}$ & $P$-value \\
\hline \multirow[t]{3}{*}{ Lymph nodules } & No & 283 & 174 & $44.0(37.0-53.0)$ & $55.98(50.32-62.28)$ & $38.82(33.04-45.61)$ & \multirow[t]{3}{*}{0.443} \\
\hline & Yes & 49 & 29 & 66.0 (38.0-NA) & $64.33(52.02-79.55)$ & $50.44(37.80-67.31)$ & \\
\hline & $X^{*}$ & 234 & 140 & $49.0(45.0-60.0)$ & $59.77(53.57-66.67)$ & $42.11(35.61-49.78)$ & \\
\hline
\end{tabular}

*No lymph nodes were collected.

also involving the lymph nodes of the pulmonary cavity and mediastinum. Thus, they may be similar in preoperative and intraoperative assessment to primary lung cancers. The incidence of lymph node changes depending on histology ranges from $5 \%$ to $33 \%$ of cases. In the case of the N2 classification, especially in metastatic kidney cancer, the decision to conduct surgery must be considered individually. Therefore, in the case of suspected changes in the nodes before resection, it is necessary to determine by available methods whether they are involved in the disease process, which will determine further management. In one study in a group of 124 patients with lung metastases lymphadenectomy or sampling was performed during metastasectomy. In 19\% metastases were found. Similar observations were made for N1 and N2 (with predominance of N2). Five-year survival was $60 \%$ in patients without metastases, with node metastases ranging from 0 to $17 \%$ [9]. The frequency of metastases was correlated with the size of lung lesions removed. In another study 5 -year survival was $66 \%$ without metastases and $30 \%$ with metastases. It has not been clearly demonstrated that lymph node removal in secondary cancer extends survival. The histological type of the tumor and the location of the primary focus affect the results of treatment $[5,10]$. Retrospective studies of various authors have shown that 5 -year survival was longer in patients with kidney cancer by $51.4 \%$, in cases of colorectal cancer it was $50.3 \%$, in sarcomas $21.7 \%$, in melanomas $25 \%$. According to other autors [11] 5-year survival rates were respectively in kidney cancer $45 \%$, in colorectal cancer $39 \%$, in soft tissue sarcomas $21 \%$, in osteogenic sarcomas $38 \%$, in $21 \%$ melanomas. With germinal tumors, survival is much better at around $68 \%$, which is mainly due to their chemosensitivity [12]. In our research, it was found that in the case of kidney cancer, 5 -year survival was $33 \%$, in colorectal cancer $40 \%$. Combining all tumors of epithelial origin in one group, it was found that 5-year survival was 44\%, 5-year survival for embryonic tumors was $78 \%$, for sarcomas $29 \%$ and for melanomas $37 \%$. Histological diagnosis differentiated survival in relation to epithelial cancers, a higher risk of death was observed for sarcomas (on the border of significance), lower for tumors of embryonic origin. No statistical significance was obtained for melanomas and tumors with a different diagnosis, probably due to the small size of these groups. The obtained results are presented in the chart (Figure 7). Survival was also studied depending on relapse after previous resection. The obtained results indicated longer survival in patients operated on several times for this reason, despite the technical difficulties associated with achieving a negative tissue margin after the procedures (Figure 8).

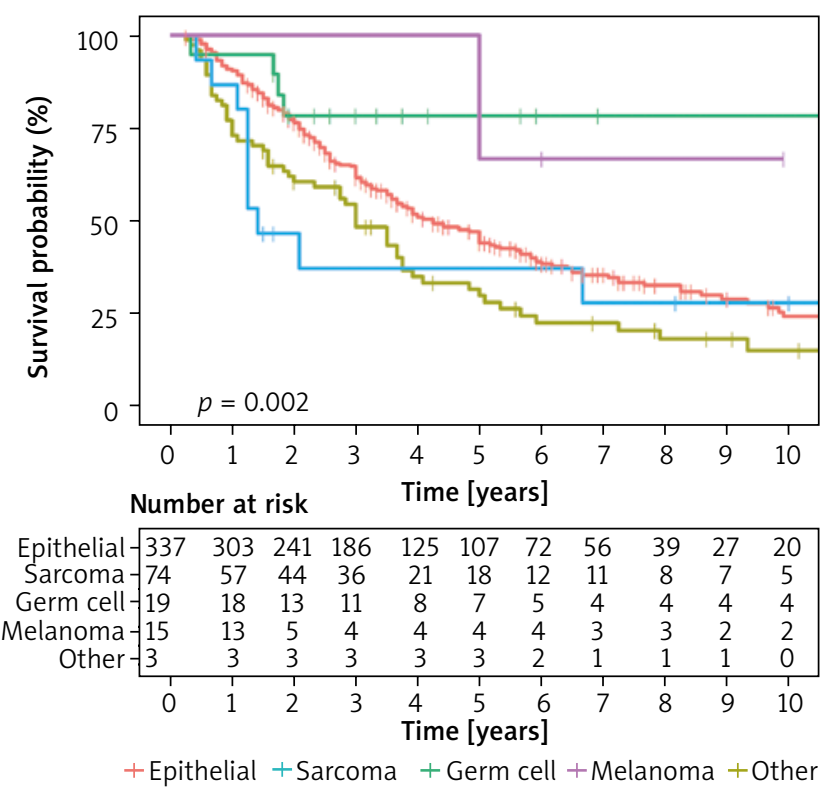

Figure 7. Histology

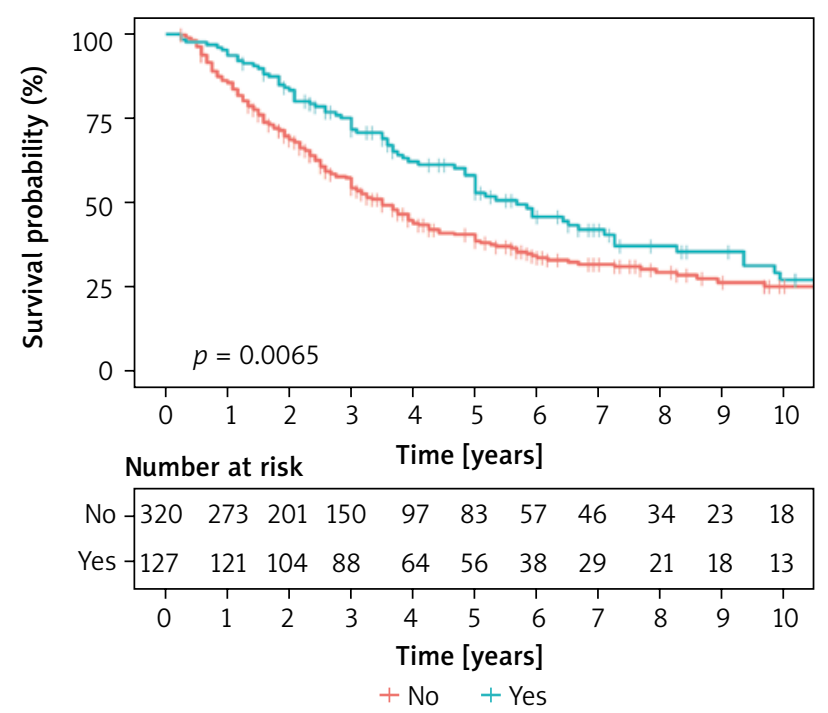

Figure 8. Relapse after resection

Patients undergoing subsequent operations had to meet the qualification conditions for such treatment. In turn, those who were disqualified from repeated procedures, in the presence of recurrence or recurrence of the disease, were more advanced in the proliferative process and thus had shorter survival. After losing the local control of the chest, the median survival drops dramatically to 
Table IX. Results of multivariate Cox regression

\begin{tabular}{|c|c|c|c|c|}
\hline Variable & & HR & $95 \% \mathrm{Cl}$ & $P$-value \\
\hline \multirow[t]{5}{*}{ Histology } & Epithelial & 1 & & \\
\hline & Sarcoma & 1.398 & $0.996-1.961$ & 0.053 \\
\hline & Germ cell & 0.315 & $0.116-0.854$ & 0.023 \\
\hline & Melanoma & 1.487 & $0.777-2.844$ & 0.231 \\
\hline & Others & 0.561 & $0.077-4.093$ & 0.568 \\
\hline \multirow[t]{3}{*}{ Maximum size } & $<2$ & 1 & & \\
\hline & {$[2,3)$} & 1.245 & $0.888-1.745$ & 0.204 \\
\hline & $3+$ & 1.628 & $1.195-2.217$ & 0.002 \\
\hline \multirow[t]{4}{*}{ Number of tumors } & 1 & 1 & & \\
\hline & 2 & 1.482 & $1.046-2.098$ & 0.027 \\
\hline & 3 & 1.410 & $0.889-2.236$ & 0.144 \\
\hline & $4+$ & 1.618 & $1.15-2.276$ & 0.006 \\
\hline \multirow[t]{4}{*}{ Number of operations } & 1 & 1 & & \\
\hline & 2 & 0.658 & $0.488-0.886$ & 0.006 \\
\hline & 3 & 0.655 & $0.401-1.069$ & 0.090 \\
\hline & $4+$ & 0.506 & $0.317-0.807$ & 0.004 \\
\hline \multirow{2}{*}{$\begin{array}{l}\text { Time from primary } \\
\text { surgery } \\
\text { [months] }\end{array}$} & $0-36$ & 1 & & \\
\hline & Above 36 & 0.647 & $0.489-0.854$ & 0.002 \\
\hline
\end{tabular}

8 months and 2-year survival in 19\% [13]. This explains why careful local control in aggressive surgical management can lead to better survival results.

Summing up the obtained results, we conclude that despite the significant initial stage of the disease, where almost $80 \%$ of patients were in the $2^{\text {nd }}$ and $3^{\text {rd }}$ risk groups, the achieved survival was longer than that obtained in other centers. Radicalism was a statistically significant positive factor. Similarly, statistically significantly longer survival was observed in patients in the first group according to the classification introduced by IRLM. The maximum tumor size above $3 \mathrm{~cm}$ was a prognostically unfavorable factor. Longer survival was observed in patients with one metastasis in the lung parenchyma. A factor positively influencing survival was higher number of operations performed in one patient, which was associated with relapse after resection or disease progression in the lung not yet operated. This indicates the need for careful monitoring of patients with secondary proliferative disease and removal of new lesions from the lungs as long as technically possible (Table IX).

\section{Disclosure}

Authors report no conflict of interest.

\section{References}

1. Pasrorino U, Buyse M, Friedel G, et al.; The International Registry of Lung Metastases. Long-Term Results of Lung Metsatasectomy. J Thoracic Cardiovasc Surg 1997; 113: 37-49.

2. Casiraghi M, De Pas T, Maisonneuve P, et al. A 10-year single- center expierience on 708 lung metastasectomies. J Thorac Oncol 2011; 6: 1373-1378.

3. Quiros R, Scott W. Surgical treatment of metastatic disease to the lung. Semin Oncol 2008; 35: 134-146.

4. Treasure T, Milosevic M. Pulmonary metastasectomy: what is the practise and where is the evidence for effectiveness? Thorax 2014; 69: 946-949.

5. Handy JR, Bremner RM, Crocenzi TS, et al. Expert Consensus Document on Pulmonary Metastasectomy. Ann Thorac Surg https://doi.org/10. 1016/athoracsur.2018.10.28

6. Naunheim K. Thoracoscopy versus open approach for Resection of Solitary Pulmonary Metastases. In: Difficult Decisions in Thoracic Surgery. Ferguson MK (ed.). Springer-Verlag London Limited 2007; 151-157.

7. Jaklitsch M, Burt B, Jett J. Surgical resection of pulmonary metastases: benefits, indications, preoperative evaluation and techniques. UpToDate 2017; 7815.

8. Jaklitsch M, Jett J. Surgical resection of pulmonary metastases: outcomes by histology. UpToDate 2017; 2796.

9. Veronesi G, Petrella F, Leo F, et al. Prognostic role of lymph node involvement in lung metastasectomy. J Thorac Cardiovasc Surg 2007; 133: 967-972.

10. Onaitis M, Peterson R, Haney J, et al. Prognostic factors for reccurence after pulmonary resection of colorectal cancer metastases. Ann Thorac Surg 2009; 87: 1684-1689.

11. Erhunmwunsee L, D'Amico T. Surgical management of pulmonary metastases. Ann Thorac Surg 2009; 88: 2052-2060.

12. Kondo H, Okumura T, Ohde Y, Nakagawa K. Surgical treatment for metastatic malignacies. Pulmonary metastasis: indication and outcomes. Int J Clin Oncol 2005; 10: 81-85.

13. Jaklitsch M, Mery C, Lukanich J, et al. Sequential thoracic metastasectomy prolongs survival by re-establishing local control within the chest. Am Assoc Thorac Surg 2001; 121: 657-667. 